Derleme Makale

Review Article

\title{
HASTA BİNA SENDROMU KAVRAMI LİTERATÜR ARAŞTIRMASI VE ÇEŞITLİ MEKÂNLARIN İÇ HAVA KALİTELERİNİN KARŞILAŞTIRILMASI
}

\author{
Kazım Onur DEMIRARSLAN ${ }^{* 1}$, Serden BAŞAK ${ }^{2}$
}

${ }^{1}$ Artvin Çoruh Üniversitesi, Mühendislik Fakültesi, Çevre Mühendisliği Bölümü, 08000, Artvin

${ }^{2}$ Artvin Çoruh Üniversitesi, Sağlık Bilimleri Fakültesi, İş Sağlı̆̆ı ve Güvenliği Bölümü, 08000, Artvin



\section{LITERATURE SURVEY OF SICK BUILDING SYNDROME CONCEPT AND COMPARISON OF INDOOR AIR QUALITY OF VARIOUS LOCATIONS}

\begin{tabular}{ll}
\hline Keywords & Abstract \\
$\begin{array}{l}\text { Indoor air quality, } \\
\text { Sick Building }\end{array}$ & When the indoor air quality is considered as a term, it is seen that it is a concept \\
Syndrome, & covering many different factors such as temperature, humidity, properties and \\
Emission, & quantities of chemical and other pollutants. This concept creates environmental \\
problems especially in banks, restaurants, government offices and healthcare & organizations where are crowded places. In these places where emissions disturb \\
indoor air quality, various physical factors such as the operating speed of the air \\
conditioner, temperature and humidity are also of great importance right along with \\
the possible presence of microbiological and chemical components. Symptoms such \\
as headache, fatigue, eye and skin irritation as well as psychological problems can be \\
found in places that are poor in terms of air quality, and these symptoms can be seen \\
in both visitors and employees. This illness, which people live in the buildings they \\
are in, is called "Sick Building Syndrome". It has been reported that when people are \\
away from the buildings where people feel uncomfortable, the symptoms of the \\
disease are completely or mostly disappeared. When the studies in the literature are \\
examined, it is seen that the pollutants that will threaten human health such as CO, \\
$\mathrm{CO}_{2}, \mathrm{O}_{3}, \mathrm{TVOC}, \mathrm{HCHO}, \mathrm{PM}_{2.5}, \mathrm{PM}_{10}$, bacteria, fungus spores are measured. By way of
\end{tabular}


measures including control techniques such as particle control, air disinfection systems, humidity control, pressure regulation systems, the indoor air quality of these various organizations is being improved day by day with technology. The aim of the study is to be examined the studies about SBS and indoor air quality in the world and Turkey, and revealed the results which are obtained by comparing.

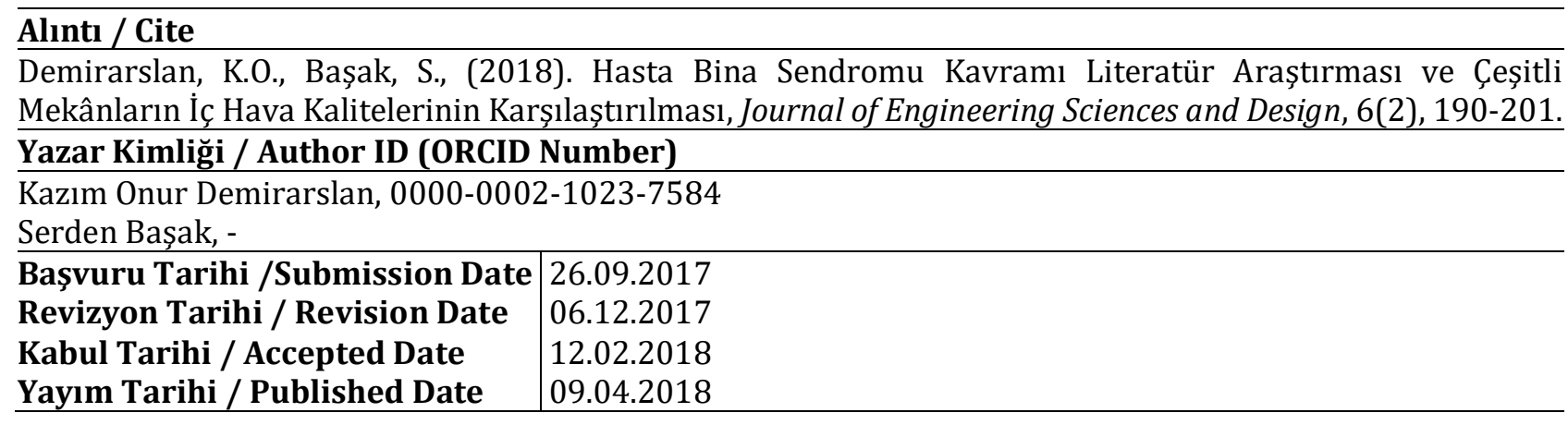

\section{Giris}

Modern kent yaşamını çevreleyen binalar; rezidanslar, avmler, plazalar, gökdelenler ve kuleler kimi zaman özel, kimi zaman toplumsal, kimi zaman da iş yaşantısının sürdürüldüğü akıllı yapılar olarak kentsel yaşam alanlarını doldurmaya ve dönüştürmeye hızlı bir biçimde devam etmektedir. Günlük eylemlerin, hareketlerin ve yaşantıların büyük bir bölümünün neredeyse tamamının kapalı mekânlarda geçtiği düşünülürse, bu kapalı mekânların toplumsal süreçte ne denli önemli bir yer kapladığı da kaçınılmaz bir gerçektir. İnsanların hızlı yaşam temposuna ayak uydurabilmeleri, daha konforlu, daha güvenli ve modern teknoloji aracılığıyla daha rahat bir yaşam sürmeleri adına tasarlanan bu binalar, aynı zamanda insan sağlığını tehdit eden, nitelikli ve verimli yaşamalarını engelleyen, çalışma yaşamında üretkenliklerini düşüren başlıca öğe olarak da karşımıza çıkmaktadır. Bir başka deyişle, insanların birbirleriyle verimli iletişim kurmalarını etkileyen, iletişim çatışmalarına neden olan etmenlerin arasında yer alan psikolojik ve psiko-nörolojik boyutta bazı olumsuz etkileri kimi zaman da hastalıkları beraberinde getirmektedir. İç ortam hava kalitesinin insan sağlığı üzerine olan etkileri giderek artan ilgi görmekte ve pek çok kaynaktan iç ortam havasına yayılan kirleticiler akut ve kronik sağlı sorunlarına sebep olmaktadır. Söz konusu hastalıklar, bireyler tarafından çoğunlukla fark edilmemekte ve birçok sorunlar yaşanmaktadır. $\mathrm{Bu}$ çerçevede mimari öğeler açısından estetik ve yüksek bir binanın iç hava kalite standartlarını yakalayabilmesi için belirli şartları yerine getirmesi gerekmektedir. Aksi taktirde kötü, sağlıksız bir yaşamın yanında hastalıklarında göstergesi olacaktır.
Bu hastalığın adı "Beyaz Yakalıların Hastalığı" ya da "Hasta Bina Sendromu (HBS)" olarak dile getirilmektedir. Yapılan araştırmalar sonucunda, söz konusu binalarda bulunanların, uyku problemi, dikkat dağınıklığı, yorgunluk, baș ağrısı, depresyon, uyuşukluk, konsantrasyon eksikliği, tat ve koku alma eksikliği, solunum yollarında, gözlerde tahriş (Obi, 2015) gibi birçok şikayetlerin artmasına da neden olduğu saptanmıştır. Bu şikayetlerin oluşmasına neden olarak, havalandırmanın yetersiz olması, dış çevreden gelen kirleticiler, bina içinden kaynaklı kirleticiler, bina yapımında kullanılan inşaat malzemeleri, yetersiz işık, uygun olmayan nem ve sıcaklık, kokular, ses ve elektromanyetik kirlilik söylenebilir. İç mekanlarda gün ışığından yararlanmak yerine, yapay aydınlatıcıların kullanılması; bireylere pozitif enerjiler yükleyen renklerin doğru kullanılmaması, iç mekan aydınlatmanın da yerinde ve gerektiği biçimde olmaması da irdelenmesi gereken öğeler olarak gösterilmektedir (Zeybek, 2014; Alyüz ve Veli, 2006; Okolie vd., 2013; Jansz, 2011). Hayatımızın çok önemli bir bölümü, kapalı alanlarda yani binaların iç mekânlarında geçmektedir. Birleşmiş Milletler tarafından yapılan bir araştırma insanların bir günlük zamanının \%88'ini kapalı ortamlarda geçirdiğini göstermektedir. Çalışılan ve/veya yaşanılan bu binalar ortam şartlarına bağlı olarak birtakım kirletici maddeler tarafından kirlenerek hastalanmaktadır (Özyaral ve Keskin, 2005; Alyüz ve Veli, 2006).

HBS ifadesi zamanının büyük çoğunluğunu bina içerisinde geçiren insanlarda görülen, tanımlanabilen, ancak kendine has bir özellik göstermeyen rahatsızlıklara yol açan durumlar için kullanılmaktadır. Ayrıca bina içerisinde çalışanlarda görülen akut sağlık sorunları veya zamanın çoğunu kapalı yerlerde geçirenlerde görülen konforla ilişkili etkiler olarak da tanımlanmaktadır. Buna göre yapılan işin cinsi, bina yașı, kapalı alanın büyüklügü, kișisel faktörler (yaș ve cinsiyet), çalıșma saatleri gibi unsurlar HBS'de etkili olmaktadır. Bir diğer 
tanımlamaya göre ise iç ortam hava kalitesinin kötü olduğu binalarda uzun süre vaktini geçiren kişilerde çeşitli semptomlar ve kirletici kaynağın yoğunluğuna bağlı olarak da bazen hastalıklar gözlendiği belirtilmektedir ve problemlere neden olan bu binalara "hasta bina" denilmektedir. Problemli binalardan kaynaklanan sağllk sorunlarını bina ile ilișkili hastalıklar, iș ile ilișkili hastalıklar ve belirtiler ile HBS olarak sınıflandırılabilir (Menteşe vd., 2009; Nur ve Juliana, 2012; Heslop, 2002). Meydana gelebilecek spesifik bir rahatsızlık tanımlanmamış olsa da şikayetlerin çoğu özellikle kapalı bir odada çalıșanlarda fazlalașmaktadır. Bir binada çalışanların \%20'sinden fazlası belirtileri taşıyorsa ve binayı terk ettiklerinde şikâyetleri azalıyorsa HBS'den söz edilebilir (Gomzi ve Bobic, 2009). HBS tarihsel süreçte 1. Dünya Savaşı sonrası binalarda kullanılan sentetik malzemelerin çeşitleri ve kullanımındaki artışı olarak ele alınmaya başlasa da, (Linder, 1995) terim ilk olarak; petrol krizinin yașandığı 1970'lerde ortaya çıkmıștır. İlk zamanlarda bina içerisinde bulunan elektronik eşyalardan kaynaklanabileceği düşünülmüş olsa da, 1984 yılında yayımlanan WHO raporuna göre dünya çapında yeni yapılan veya tadilata uğramış binaların \%30'undan fazlası için düşük iç hava kalitesi hakkında şikâyetlerde bulunulduğu, HBS'ye neden olan sebeplerin başında; petrol krizi nedeniyle o dönemlerde yapılan binaların çok izole olması, iklimlendirme sistemlerindeki eksiklikler, yaşanan bakım ve onarım sorunları ile yetersiz projelendirmenin geldiği görülmüștür. HBS' ye sebep olan nedenlerden bir diğeri de bina yapımında kullanılan malzemelerin türlerine göre salınım yapan gazlar, uçucu organik bileşikler (UOB), küfler, kullanılan hafif endüstriyel kimyasallar, eksik veya yetersiz hava filtrasyonu sayılabilmektedir. Bunların sebep olduğu rahatsızlıklar arasında genellikle göz kaşıntısı, deri lejyonları, solunum yollarında alerji, akut astım, akut ve kronik yorgunluk sendromu, ileri düzeyde tükenmişlik sendromu, nemden kaynaklı romatizmal hastalıklara bağlı ağrı gibi şikâyetler bulunmaktadır. HBS en yaygın olarak ofis binalarında görülse de okul ve diğer binalarda da görülmektedir (URL-1; Joshi, 2008; URL-2).

Yapılan bu çalışmada literatür incelenerek kapalı ortamlardaki iç hava kalitesini bozan emisyonlar ile meydana gelen rahatsızlıklar incelenmiş; HBS üzerine kaynak eksikliği giderilmeye çalıșılmıș bununla birlikte ileride yapılacak olan iç hava kalitesi incelemeleri ve değerlendirmeleri için bir temel oluşturması planlanmıştır.

\section{2. İç Hava Kalitesi ve Kirleticiler}

İnsanlar zamanlarının büyük bir bölümünü ev, işyeri ve okul gibi kapalı ortamlarda geçirmektedir. Bu nedenle, iç ortam havasının halk sağlığı üzerinde çok büyük bir etkisi vardır. İnsan popülasyonlarının yaşamları boyunca kaçınılmaz olarak vakitlerini geçirdikleri iç mekânlar, hava kalitesinin belirli bir düzeyde tutulması gereken yaşam alanlarıdır. Bu alanlar; yaşamımızın daha başlarında kreş ve gündüz bakımevleri, okullar, sonrasında çalışma yaşamının başlaması ile işyerleri olup özellikle, sosyalleşilerek fiziksel temasta bulunulan ve aynı havanın solunduğu yoğun olarak kullanılan geniş ve büyük mekânlardır. Evler ise insanların günlük en az 8'er saatlerini geçirdikleri çalışma ve ikamet yerleridir. Bu mekânlardan kreşler ve ilkokullar, hassas grup olarak nitelendirilen çocukların bulundukları yaş aralıklarındaki fizyolojileri nedeniyle bağışıklık sistemlerinin henüz gelişmediği, solunum seviyelerinin daha düșük olduğu bu nedenle de ayrı olarak değerlendirilmeleri gereken grupta yer almaktadır (Menteşe vd., 2009). İç hava kalitesi insanların yaşadığı mekândaki havanın temizliği, oksijen seviyesi, kirletici gazların oransal dağılımı, havadaki serbest radikallerin miktarı, nem oranı değişkenleri olarak tanımlanabilmekte ancak değişkenlerin yarattığı kalite algısı da insandan insana farklılık gösterebilmektedir. Hava kalitesi için kesin sınırlar belirlemek maalesef gerçekçi bir yaklaşım olamamaktadır. Bu nedenle kabul edilebilir iç hava kalitesi terimi kullanılmaktadır. $\mathrm{Bu}$ tanım ASHRAE 62-1989 Standardına göre şöyle açıklanmaktadır: İçinde bilinen kirleticilerin, yetkili kuruluşlar tarafından belirlenmiş zararlı konsantrasyonlar seviyelerinde bulunmadığı ve bu hava içerisinde bulunan insanların \%80 veya daha üzerindeki oranının havanın kalitesiyle ilgili herhangi bir memnuniyetsizlik hissetmediği havadır (Aslan 1997; Ertürk 2017). Bina içi hava kalitesi insan sağlı̆̆ açısından büyük önem taşır. Hava kalitesine iyi denebilmesi için sıcaklığın $19-23^{\circ} \mathrm{C}$ arasında, göreceli nem oranının \% 40-60 arasında olması ve hava akım hızının 0,1 $\mathrm{m} / \mathrm{sn}$ den fazla ya da az olmaması gerekmekte, nem oranının \%70'den yüksek olması küf mantarı oluşma riskini artırmaktadır. Hava akım hızında $0,2 \mathrm{~m} / \mathrm{sn}^{\prime}$ in üzerinde bir artış olması durumunda ise hava sıcaklığında $1^{\circ} \mathrm{C}$ 'lik düşüş meydana gelmektedir. (Çobanoğlu ve Kiper, 2006). İç hava kalitesinde, çevresel etmenlerle birlikte, kullanılan yapı malzemelerinin de büyük önemi bulunmaktadır (Alptekin, 2007). İç ortam hava kirleticileri, yapı bileșenleri ve mekân içindeki döșeme ve dekorasyon malzemelerinden gelen kirleticiler, iç mekânlarda, insanlar ve makinelerden gelen kirleticiler, dış ortamdan, havalandırma ve hava sızıntısı ile gelen kirleticiler şeklinde sınıflandırılabilir (Coşgun, 2008). Bu kaynaklardan gelen ve iç hava kalitesini bozan kirleticilere örnek olarak ise CO, PM, UOB, Kalıcl Organik Kirleticiler (KOK), NO, $\mathrm{SO}_{2}$, mikroorganizmalar, $\mathrm{O}_{3}$, elyaf, formaldehit gibi maddeler ve bileşikler sayllabilmektedir (Aslan, 1997). Diğer taraftan ise bakteri, mantar, mantar sporlarl, virüsler ve polenler ile onların fragmentlerini içeren, biyolojik kökenli havadan kaynaklı tüm organik tozlar genel olarak biyoaerosol olarak adlandırılmaktadır. Bu biyolojik partiküller kendi bașlarına sağlık riski oluşturmakla beraber; bu canlıların metabolizma ürünleri olan endotoksinler, ekzotoksinler ve 
mitotoksinler de insan sağlı̆̆ üzerinde olumsuz etkilere yol açmaktadır. Biyoaerosollerin kronik alerjik rinit, astım ve hipersensitiv pnömani gibi çeşitli hastalıklara neden olduğu belirlenmiştir. Bu hastalıklar haricinde, henüz tam olarak sebep olduğu etkenler kesinleşmediği için semptom olarak kalan HBS de son zamanlarda en çok dikkat çeken konulardan biridir. İç ortam hava kirleticilerin kaynaklarında iç mekânda bulunan bireylerin de katkısı yadsınamaz. Yapılan yemek pişirme, temizlik ve sigara içimi gibi bazı aktiviteler hava kalitesini oldukça fazla düșürebilmektedir. Özellikle temizlik yaparken kirli filtreye sahip yüksek emiş güçlü elektrik süpürgeleri bir yandan tozları ve kirleri emerken diğer yandan da gözle görünemeyecek kadar küçük toz ve diğer kirleticileri büyük bir hızla iç mekân havasına salıvermektedir. Diğerleri bina malzemeleri, ahşap, halı gibi tüketim malzemeleri, yapıștırıcılar, boyalar, ev bitkileri ve banyo malzemelerinden yayılırlar. Son olarak da bazı iç ortam kirleticileri dış ortamda üretilirler. Ancak pencere ve kapılardan iç ortama girerler (Menteșe vd., 2013).

İç hava kalitesini bozan ve kirlilik oluşturan zararlı maddeleri ancak çeşitli gruplar altında toplayarak tanımlamak mümkündür. İç hava kalitesini bozan kirletici grupları aşağıdaki gibi sıralamak mümkündür (Eser, 2006):

- Solunan havadaki karbondioksit oranı (insanların ve canlıların solunumları ve yanma kaynaklıdır)

- Koku (insan kaynaklıdır)

- Mikroorganizmalar (çevre ve insan kaynaklıdır)

- Nem (çevre ve pişirme gibi insan faaliyetleri kaynaklıdır)

- Radon gazı (toprak kaynaklıdır)

- Organik buharlar (kullanılan eşya ve bina elemanları kaynaklıdır)

- Toz (çevre ve kullanılan eşya kaynaklıdır)

- Sigara dumanı (insan kaynaklıdır)

Tablo 1'de ise iç hava kirleticileri ve potansiyel kaynakları verilmektedir.

Tablo 1. İç hava kirleticileri ve potansiyel kaynakları (Bulgurcu vd., 2008; İstanbulluoğlu ve Tekbaş, 2013)

\begin{tabular}{|c|c|c|}
\hline Kirleticiler & \multicolumn{2}{|c|}{ Potansiyel Kaynakları } \\
\hline Uçucu Organik Bileşikler & $\begin{array}{l}\text { Parfümler, saç spreyleri } \\
\text { Mobilya cilaları } \\
\text { Temizlik solventleri } \\
\text { Hobi ve sanat malzemeleri } \\
\text { Pestisitler } \\
\text { Halı ve iplik boyaları } \\
\text { Tutkal, yapıștırıcı ve sızdırmazlık } \\
\text { malzemeleri }\end{array}$ & $\begin{array}{l}\text { Boyalar, vernikler, yapıştırıcı bantlar } \\
\text { Ahşap koruyucular } \\
\text { Kuru temizlenmiş elbiseler, güve ilaçları } \\
\text { Hava tazeleyici kokular } \\
\text { Depolanmış yakıtlar ve otomotiv } \\
\text { ürünleri } \\
\text { Kirlenmiş sular } \\
\text { Plastikler }\end{array}$ \\
\hline Formaldehit & $\begin{array}{l}\text { Parçacık tutucular, kontraplaklar } \\
\text { Dolaplar, mobilyalar }\end{array}$ & $\begin{array}{l}\text { Formaldehit köpük yalıtım katkıları } \\
\text { Halı ve kumaşlar }\end{array}$ \\
\hline Pestisitler & $\begin{array}{l}\text { Böcek ve karınca öldürücüler } \\
\text { Fare ilaçları }\end{array}$ & $\begin{array}{l}\text { Mantar ilaçları, mikrop öldürücüler } \\
\text { Ot ilaçları }\end{array}$ \\
\hline Kurşun & Kurşun esaslı boyalar & Diş tozlar ve toprak \\
\hline $\begin{array}{l}\text { Karbondioksit } \\
\text { Karbon monoksit } \\
\text { Azot dioksit }\end{array}$ & $\begin{array}{l}\text { Uygunsuz çalıştırılan gaz veya yağ } \\
\text { kazanları-sıcak su ısıtıcıları, ocaklar, } \\
\text { odun sobaları }\end{array}$ & $\begin{array}{l}\text { Havalandırmasız gaz sobaları-kerosen } \\
\text { ısıtıcılar } \\
\text { Tütün ürünleri, gazlı pişirme sobaları } \\
\text { Araç egzozları }\end{array}$ \\
\hline Kükürt dioksit & Kükürt içeren yakıtların yanması & \\
\hline Solunabilir Parçacıklar & $\begin{array}{l}\text { Ocaklar, odun sobaları } \\
\text { Havalandırmasız gaz ısıtıcıları }\end{array}$ & $\begin{array}{l}\text { Tütün ürünleri } \\
\text { Havalandırmasız kerosen ısıtıcıları }\end{array}$ \\
\hline Çevresel Tütün Dumanı & Tütün ürünleri & \\
\hline Biyolojik Kirleticiler & $\begin{array}{l}\text { Bitkiler, hayvanlar, kușlar, insanlar } \\
\text { Yastıklar, yataklar, ev tozları } \\
\text { Islak veya nemli malzemeler }\end{array}$ & Durgun sular \\
\hline Asbest & $\begin{array}{l}\text { Boru ve kazan yalıtımı, tavan ve } \\
\text { döșeme levhaları }\end{array}$ & $\begin{array}{l}\text { Dekoratif spreyler, kaplama ve } \\
\text { lambriler }\end{array}$ \\
\hline Radon & $\begin{array}{l}\text { Toprak ve kaya, bazı bina } \\
\text { malzemeleri }\end{array}$ & Yer altı suları \\
\hline Kalıcı Organik Kirleticiler & $\begin{array}{l}\text { Pestisitler, Poliklorlu Bifeniller (PCB), } \\
\text { Dioksinler ve Furanlar , Polibromlu } \\
\text { Bifeniller (PBB) }\end{array}$ & $\begin{array}{l}\text { Elektrik tesisatı, boyalar, alev } \\
\text { geciktiriciler, kağıt ürünleri, pestisitler }\end{array}$ \\
\hline
\end{tabular}

\section{HBS Belirtileri ve Görülen Rahatsızlıklar}

İç hava kalitesinin insan performansı üzerindeki etkisi bilinen bir gerçektir. İnsan konforu ve üretkenliği için solunan havanın \%40-60 izafi nem içermesi ve çalıșma ortamının $19-20{ }^{\circ} \mathrm{C}$ 'de olması gerektiği saptanmış bulunmaktadır. ABD'deki binaların \%20-30'unun HBS'ye neden olacak 
özelliklerde olduğu hesaplanmaktadır. Amerikan Çevre Koruma Ajansı (EPA) verilerine göre HBS mücadele edilmesi gereken ilk 10 sağllk sorunu arasında 4. sıraya yerleşmiş̧ir (Ağca, 2005). Bir başka örnek olarak, Danimarka'da 3507 kişi üzerinde yapılan bir araştırmada incelenen deneklerin \%27'sinde göz, burun ya da boğaz irritasyonu ve \%36'sında ise baş ağrısı, yorgunluk, halsizlik gibi HBS ile bağlantılı genel belirtiler saptanmıștır (Ağca, 2005). ABD'de yapılan bir araştırmaya göre, gökdelenlerde çalışanların $\% 20$ 'sinin iş performanslarının etkilendiği, \%710 'unun ise yorgunluk, burun tıkanıklığı, baş ağrısı, solunum güçlüğü ve göz irritasyonu gibi ciddi sorunlar yaşadıkları, kişi başına 12 litre/saniye dış hava ile havalandırılan ofislerde çalışanların, 24 litre/saniye ile havalandırılan ofislerdekine oranla \%35 daha fazla hastalık izni kullandıkları belirlenmiştir. Avrupa Birliği Komisyonunun 1989 yllında yayınladığı raporda ise, Amerika Birleşik Devletlerinde yapılan bir çalışmada 600 ofis çalışanının \% 20'sinde, yine İngiltere'de yapılan bir çalışmada 46 binada 4373 çalışanın \% 29'unda HBS'nin en az 5 karakteristik semptomunun varlığ gösterilmiştir (Başak vd., 2016). Singapur'daki işyerlerinde 1998 yılında yapılan bir çalışmada da 2856 kişinin yaklaşık olarak \% 19,6'sında HBS'nin tipik belirtilerinin olduğu görülmüştür (Başak vd., 2016). Geçtiğimiz yıllarda Avrupa ve Kuzey Amerika'da yapılan çok sayıda araştırma ofis çalışanlarında HBS'nin yoğun olduğunu göstermiştir. Hong Kong ve Shenzhen bölgesinde 469 ofis çalışanı üzerinde yapılan anket çalışması sonucunda katılımcıların yarısından fazlasında HBS belirtilerinin varlı̆̆ını gösteren cevaplar alınmıştır (Gou, Lau 2012). Abdul Wahab ve diğerleri (2015) tarafindan Umman Sultan Kabus Üniversitesi ana kütüphanesinde yapılan çalışmalarda, burada çalışan kişilerde ve öğrencilerde sinüzit, boğaz kuruluğu ve göz iltihabı gibi rahatsızlıklar belirlenmiştir. Malezya'da okullarda yapılan araştırmalarda öğrencilerin baş dönmesi, bulantı gibi şikâyetlerde bulundukları ortaya çıkmış bunların yanında da burun akıntısı, boğaz ağrısı, öksürük, hırıltılı nefes gibi problemlerde bildirilmiştir (Salleh vd., 2013). Kuzey Kıbrıs Türk Cumhuriyeti'nde HBS vakaları en az 909 konutta görüldüğü saha çalışmaları ile belirlenmiștir. Buradaki binalarda yanlış havalandırma, yetersiz ısı dağılımı, izolasyonlardaki yetersizlikler en çok yaşanan problemlerdendir (Obi, 2015). Çin'de HBS'deki hızlı artış son yıllarda halk sağlığı kuruluşlarının ilgi odağı haline gelmiştir (Linyan,
2015). İç mekân kalitesinin artılması ile de Lockheed'de üretimde $\% 15$ artış, devamsızlıkta $\% 15$ azalma, West Bend Mutual Insurance'da sigorta işlemlerinde \%15 artış, ING Bank'ta devamsızlıkta $\% 15$ azalma, Verifone'da üretimde $\% 15$ artış ve devamsızlıkta \%40 azalma sağlanmıștır. Benzer literatür çalışmalarında kaliteli iç ortama sahip okullarda da öğrenmenin kolaylaştığı ve devamsızlığın azaldığı belirtilmektedir (Başak vd., 2016). Sahlberg ve diğerleri (2002) tarafından İsveç Uppsala'da 38 okulda yapılan çalışmada, yüksek konsantrasyonlarda karen, limonen, tolüen, ksilen, alfa piren gibi kimyasallar bulunmuş ayrıca $\mathrm{NO}_{2}$ ve CO gibi kirleticiler de gözlemlenmiștir. $\mathrm{Bu}$ kirleticilerin de HBS semptomlarını tetiklediği rapor edilmiștir. Türkiye'de yapılan ve banka, büro ile Aile Sağlığı Merkezi'nde farklı zamanlarda yapılan bir çalışmada sıcaklık ve nemin yanı sıra $\mathrm{CO}_{2}$ ölçümlerine göre, havalandırılmayan mekânların çoğunlukla 800 ppm'in üzerinde bir $\mathrm{CO}_{2}$ konsantrasyonuna sahip olduğu tespit edilmiştir. $\mathrm{Bu}$ mekânlarda çalışanlar $\mathrm{CO}_{2}$ cihazındaki sonuçları görmediklerinde çalışmaya devam etmişlerdir. Ancak çalışanlar bilgilendirilip $\mathrm{CO}_{2}$ cihazı sonuçları kendilerinin görebileceği gibi yerleştirildiğinde $\mathrm{CO}_{2}$ 800-1000 ppm konsantrasyona ulaştığında, çalışanlar bulundukları mekanları havalandırıp $\mathrm{CO}_{2}$ miktarının düșmesini sağlamıșlardır (Basak vd., 2017). Bu durum doktor veya banka çalışanı gibi farklı sektörlerden de olsa çalışanların, konu hakkında bilgilendirildiklerinde ve ortamda bir cihaz bulunduğunda $\mathrm{CO}_{2}$ konsantrasyonunu azaltmak için eyleme geçtiklerini göstermektedir.

İç hava kalitesini etkileyen kirletici türlerine maruz kalındığında insanlarda çeşitli rahatsızlıklar ve semptomlar görülmektedir. Bu kirleticilere maruz kalındığında ortaya çıkan HBS, Bina İlişkili Hastalıklardan olan Kawasaki Sendromu ve Kötü Koku Sendromu çalışanlarda verim düşüklüŭüne, ağır hastalıklara hatta ölümlere neden olmaktadır (Alptekin 2007). Yaşanan Semptomların birçoğu toksik etkileri bilinen yüksek orandaki kimyasallar sonucu oluşmakta, diğerleri ise bina içerisinde bulunan diğer alerjen maddelerden meydana gelmektedir. HBS'de en sik görülen semptom genellikle bir yorgunluk hissidir. $\mathrm{Bu}$ his genelde kapalı ortama girdikten birkaç saat içinde başlamaktadır ve alanı terk edişten birkaç dakika sonra düzelmektedir. Bunun yanında burun tıkanıklığı, hapşırma ve burun akıntısı gibi rahatsızlıklar da görülmektedir (Ersoy 2010). Yaygın olarak görülen belirtiler Tablo 2'de verilmektedir (URL-2, Bulgurcu vd., 2008): 
Tablo 2. HBS'da en sık görülen belirtiler

\begin{tabular}{|l|l|}
\hline Baş ağrısı & Teneffüs zorlukları \\
\hline Göz, boğaz, burun tahrişi & Göz sulanmaları ve kızarıklıkları \\
\hline Kuru öksürük & Ateşlenme \\
\hline Ciltte döküntü & Titreme \\
\hline Baş dönmesi, bulantı & Hızlı kalp atışı \\
\hline Konsantrasyon bozukluğu & Kas ağrıları \\
\hline Yorgunluk & İșitme kayıpları \\
\hline Kokulara karşı hassasiyet & Ağız ve burun içi kuruluğu \\
\hline Burun kanamaları & Kas seğirmesi \\
\hline Öksürük & Tanımlanamayan alerjik reaksiyonlar \\
\hline
\end{tabular}

Belli bir binada yaşarken veya çalıșırken ortaya çıkan ancak bu ortamdan uzaklaşınca kaybolan semptomlar "HBS semptomları" olarak adlandırılır. Yakınmalar belli bir oda, bölüm ya da binanın geniş bir bölgesinin tümünde görülebilmektedir. Semptomlar binada geçirilen zaman ile de doğrudan ilişkili olmakla beraber, çoğunlukla özel bir nedene bağlanamamaktadır. Bu sendromda, semptomlar iş yerinden ayrılınca azalmakta veya bütünüyle yok olmakta, söz konusu mekâna dönülünce tekrarlamaktadır (Otlu 2012). Bina ilişkili hastalıkları HBS'den ayıran en önemli fark ise, belirtilerinin klinik olarak tanımlanabilmesi ve nedenlerinin açıkça belli olmasıdır. Bu gruba giren şikâyetler, HBS rahatsızlıklarının tersine, kullanıcının yapıyı terk etmesinden sonra da sürmektedir. Teşhisi konmuş ve belirtileri tanımlanmış rahatsızlıkları kapsayan bina ilişkili hastalıklar, insan sağlığı için daha tehlikeli bir durum ortaya çıkarmaktadır (Alptekin 2007; Quagraine ve Boschi 2006).

İç mekan hava kalitesini bozan ve HBS'ye yol açan kirleticiler ve yol açtığı rahatsızlıklar Bulgurcu ve diğerleri (2008) tarafından Tablo 3'teki gibi özetlenmiştir.

Tablo 3. İç mekân hava kalitesini bozan ve HBS'ye yol açan kirleticiler ve yol açtığı rahatsızlıklar

\begin{tabular}{|c|c|}
\hline $\begin{array}{l}\text { İç Mekân } \\
\text { Kirleticisi }\end{array}$ & Etkileri \\
\hline $\begin{array}{l}\text { Uçucu } \\
\text { organik } \\
\text { bileșikler }\end{array}$ & Kanserojen olup bu kirleticilerin çoğu sinirsel/davranışsal etkili, zehirleyici, karaciğer ve kalbi etkileyicidir \\
\hline Formaldehit & Alerjik tepkilere ve zehirlenmelere yol açabilir \\
\hline Pestisitler & Patolojik-alerjiktir. Birçoğu beyni ve karaciğeri zehirleyici özelliktedir \\
\hline Kurșun & Patolojik-alerjiktir. Beyni zehirleyici ve geriye dönülmez davranıșsal etkilere neden olur \\
\hline $\begin{array}{l}\text { Karbon } \\
\text { monoksit }\end{array}$ & $\begin{array}{l}\text { Uyussturucu etkilidir. Boğulmaya yol açar, sağlıklı yetişkin insanlarda iş gücünü azaltır, eklem ağrıları, göz } \\
\text { küçülmesi gibi etkileri olup kalp-akciğer uyumsuzluğunu şiddetlendirir }\end{array}$ \\
\hline $\begin{array}{l}\text { Karbon } \\
\text { dioksit }\end{array}$ & $\begin{array}{l}\text { Solunumu uyarıcı etkisi vardır. İnsanlarda yorucu görevleri yapma kabiliyetini azaltır, böbreklerde ve } \\
\text { akciğgerde yapısal değişiklikler görülmektedir. Uyuşturucu etkisi de bulunmaktadır }\end{array}$ \\
\hline Azot dioksit & $\begin{array}{l}\text { Uyuşturucu ve kanserojen etkisi vardır. Ayrıca astım hastalarında ve çocuklarda ciğer fonksiyonlarında } \\
\text { azalma görülür. Bağışıklık sistemini etkiler }\end{array}$ \\
\hline $\begin{array}{l}\text { Kükürt } \\
\text { dioksit }\end{array}$ & Akciğer fonksiyonlarını azaltır, uyuşturucu, alerjik ve kanserojen etkilere sahiptir \\
\hline $\begin{array}{l}\text { Biyolojik } \\
\text { kirleticiler }\end{array}$ & Enfeksiyonlara, alerjik reaksiyonlara ve zehirlenmelere neden olabilir \\
\hline $\begin{array}{l}\text { Tütün } \\
\text { dumanı }\end{array}$ & $\begin{array}{l}\text { Mukozayı tahriş etmekte, dolaşım sisteminde strese ve çocuklarda şiddetli solunum güçlüklerine neden } \\
\text { olmaktadır }\end{array}$ \\
\hline $\mathrm{PAH}$ & Tahriș edici bir özelliğe sahiptir ve dolaşım sistemini etkileyebilir \\
\hline Asbest & Uzun süre solunumda asbest hastalığı olan mezotelizma oluşturur \\
\hline
\end{tabular}

\section{Mekân Hava Kalitesinin Arttırılması}

Mekân insan veya canlı bir organizma tarafından çeşitli malzemeler kullanılarak yapılmış, içerisinde yer alan canllya huzur ve güven veren bir çevre olarak tanımlanabilmektedir. Ayrıca mekânlar insanların fizyolojik, psikolojik ve toplumsal ihtiyaçlarını da karşılayabilmelidir (Demirarslan 
2006). Bu nedenle içinde yaşanılan ortamların hava kalitesini arttırmak yukarıda tanımlanan huzur ve güven veren bir çevrenin oluşturulmasında önemli bir adım olacaktır. İç hava kalitesinin geliştirilmesi için yöntemler aşağıdaki gibi sıralanabilir (Eser 2006; Okolie ve Adedeji, 2013).

- Öncelikle kirlilik kaynaklarının kontrolü ve azaltılması gerekir. Örneğin sigara içiminin yasaklanması, zararlı gazlar çıkaran halı v.s. malzemelerin iç hacimlerde kullanılmaması bu önlemler arasında sayılabilir.

- Bina içerisindeki kirletici kaynakların çıarılması ya da yenilenmesi gerekir.

- İç ortamdaki havanın filtre edilmesi ve temizlenmesi gerekir.

- İç hava kalitesinin sağlanmasında günümüzde hala en yaygın kullanılan ve en etkin yöntem havalandırmadır. Yeterli miktarda taze havanın iç mekânlara verilmesiyle içerdeki hava kalitesi istenilen düzeye getirebilir.

- Bina sakinlerinin bu konuda eğitilmesi önemlidir.

1900'lü yılların başından ortalarına kadar binalardaki havalandırma miktarı standardı her bir bina sakini için $7 \mathrm{l} / \mathrm{s}$ iken, 1973'deki petrol ambargosunun sonucu enerji tasarrufu kaygisiyla havalandırma miktarının kişi başına 2,36 l/s' ye kadar düştüğü görülmektedir. Çoğu durumda 2,36 $\mathrm{l} / \mathrm{s}^{\prime}$ ye düsşen bu dış hava miktarının, hem konfor hem de sağlık şartlarını karşılamakta yetersiz kaldığı görülmüştür. Eğer bir binanın ısıtma, havalandırma ve iklimlendirme sistemi havayı insanlara efektif bir şekilde dağıtamıyorsa bu HBS'de önemli bir etken olarak karşımıza çıkabilir. Minimum enerji tüketimiyle kabul edilebilir bir iç hava kalitesine ulaşabilmek için ASHRAE (American Society of Heating Refrigerating and Air Conditioning Engineers; ASHRAE, 1984 yllında kurulmuş, bina sistemleri, enerji verimliliği, iç hava kalitesi, sürdürülebilirlik alanlarında çalışan uluslararası bir dernektir) kişi başına düşen dış hava miktarını bir standarda bağlamıştır. Standart 62' ye göre, eğer dış hava kalitesi yeterli ise, Tablo 4'de gösterilen miktarlarda dış hava söz konusu hacimlere temin ediliyorsa, istenilen iç hava kalitesi elde edilir. Tablo 4' de dış hava miktarları kişi başına l/s veya alan başına $1 / s . m^{2}$ verilmiștir. Ancak söz konusu havalandırma değerleri hala tartışılmakta olan değerlerdir. Yeterli havalandırmayı, kaynaktan bağımsız olarak, her koşul için geçerli genel değerlerle temin etmek mümkün değildir. Belki de havalandırma miktarları, aynı ısı kaybı ve kazancı hesaplarında yapıldığı gibi, her bina için kaynak tanımına bağlı olarak hesaplanmalıdır. Böyle bir hesap yöntemi, kaynak tanımları yapılamadığı ve zararlı düzeyleri belirlenemediği için günümüzde verilememektedir (Öntaş 2008; URL-3).

Buradan hareketle son yllarda gelişen tekniklerden biri talep kontrollü havalandırmadır. Bu sistemde hava kalite sensöründen veya $\mathrm{CO}_{2}$ sensöründen kumanda alan bir havalandırma sistemi ihtiyaç olduğunda ve talep edildiğinde devreye girmektedir. Özellikle kafe, bar gibi yoğun havalandırma gereken ve enerjisi tüketimi yüksek olan yerlerde bu sistem giderek yaygınlaşmaktadır. Bir hacme gönderilecek veya çekilecek hava miktarı kirleticilerin veya kokunun yoğunluğuna bağlıdır. Endüstriyel ve ticari uygulamalarda üretilen ısı ve prosese bağlı olarak ilave artırım faktörleri gereksinebilir. Saatteki hava sirkülasyon miktarı, bir odaya beslenecek taze hava miktarının hesaplanmasında önemli bir faktördür. Tablo 5'de Avrupa tarafindan tavsiye edilen hava değişim sayıları verilmiştir. Bu değerler DIN 1976 T.2 üzerinde çalışan yerel otoriteler tarafından teklif edilmiştir. Bu hesaplarda kişi başına hava ihtiyacı 20-50 $\mathrm{m}^{3} / \mathrm{h}$ arasında bir değer olarak göz önüne alınmıştır. Buna göre ofis, dükkân, depo, otel, spor tesisleri gibi ticari tesisler için gerekli hava miktarları Tablo 5'de verilmektedir (Öntaş 2008). 
Tablo 4. Ticari tesisler için (ofisler, dükkânlar, depolar, oteller, spor tesisleri) tavsiye edilen dış hava miktarları (Sunaç ve Kenber 2000; Öntaş 2008)

\begin{tabular}{|c|c|c|c|c|}
\hline \multicolumn{5}{|c|}{ Hesaplanan Minimum Dış Hava İhtiyacı } \\
\hline Uygulama & $\begin{array}{l}\text { İnsan } \\
\text { sayısı } \\
(\text { Kişi/100 } \\
\left.\text { m² }^{2}\right)\end{array}$ & $\begin{array}{l}\text { l/s } \\
\text { kişi }\end{array}$ & $1 / \mathbf{s ~ m}^{2}$ & Açılklamalar \\
\hline $\begin{array}{l}\text { Kuru } \\
\text { temizleme, } \\
\text { çamaşırhane }\end{array}$ & & & & Kuru temizleme işlemleri daha fazla hava gerektirebilir \\
\hline $\begin{array}{l}\text { Ticari } \\
\text { çamaşırhane }\end{array}$ & 10 & 13 & & \\
\hline $\begin{array}{l}\text { Ticari kuru } \\
\text { temizleyici }\end{array}$ & 30 & 15 & & \\
\hline Depo & 30 & 18 & & \\
\hline $\begin{array}{l}\text { Jetonlu } \\
\text { çamaşırhane }\end{array}$ & 20 & 8 & & \\
\hline $\begin{array}{l}\text { Jetonlu kuru } \\
\text { temizleme }\end{array}$ & 20 & 8 & & \\
\hline $\begin{array}{l}\text { Yiyecek ve } \\
\text { içecek hizmeti }\end{array}$ & & & & İlave duman uzaklaştırıcı cihaz gerekebilir \\
\hline Lokanta & 70 & 10 & & \\
\hline $\begin{array}{l}\text { Kafeterya, fast } \\
\text { food }\end{array}$ & 100 & 10 & & \\
\hline $\begin{array}{l}\text { Bar, kokteyl } \\
\text { salonu }\end{array}$ & 100 & 15 & & \\
\hline $\begin{array}{l}\text { Mutfaklar } \\
\text { (pişirme) }\end{array}$ & 20 & 8 & & $\begin{array}{l}\text { Davlumbaz egzozu, besleme havası için daha fazla havalandırma havası gerekebilir. } \\
\text { Dışarıdan alınan kabul edilebilir kalitedeki havanın miktarı } 7.5 \mathrm{l} / \mathrm{sm}^{2} \text { değerinden az } \\
\text { olmamalıdır }\end{array}$ \\
\hline $\begin{array}{l}\text { Garajlar, } \\
\text { tamirhaneler } \\
\text { Servis } \\
\text { istasyonları } \\
\text { Kapalı garajlar }\end{array}$ & & & 7,5 & $\begin{array}{l}\text { İnsanlar arasındaki dağıtım, çalışma yerleri ve çalışan makinaların yoğunluğu } \\
\text { dikkate alınmalıdır. Motorların çalıstığı standlar, motor egzozunu dışarı zorlamış } \\
\text { olarak atan sistemleri içermelidir. Kirletici sensörleri havalandırmanın kontrolü } \\
\text { amacı ile kullanılabilir }\end{array}$ \\
\hline $\begin{array}{l}\text { Otomobil } \\
\text { tamirhaneleri }\end{array}$ & & & 7,5 & \\
\hline $\begin{array}{l}\text { Alışveriş } \\
\text { merkezleri } \\
\text { satış katları ve } \\
\text { sergi katları }\end{array}$ & & & & \\
\hline $\begin{array}{l}\text { Bodrum ve } \\
\text { zemin }\end{array}$ & 30 & & 1,50 & \\
\hline Üst katlar & 20 & & 1,0 & \\
\hline Depo odaları & 15 & & 0,75 & Normal olarak transfer havası ile beslenir ve yerel egzoz yapılır. Resirkülasyon \\
\hline $\begin{array}{l}\text { Soyunma } \\
\text { odaları }\end{array}$ & & & 1,0 & tavsiye edilmez \\
\hline $\begin{array}{l}\text { Yürüme } \\
\text { alanları } \\
\text { (moller) }\end{array}$ & 20 & & 1,0 & \\
\hline $\begin{array}{l}\text { Yükleme ve } \\
\text { kabul alanları }\end{array}$ & 10 & & 0,75 & \\
\hline Depolar & 5 & & 0,25 & \\
\hline Sigara odaları & 70 & 30 & & \\
\hline Özel dükkânlar & & & & \\
\hline Berber & 25 & 8 & & \\
\hline $\begin{array}{l}\text { Güzellik } \\
\text { salonları }\end{array}$ & 25 & 13 & & \\
\hline $\begin{array}{l}\text { Zayıflama } \\
\text { salonu }\end{array}$ & 20 & 8 & & Bitki büyümesini en iyi sağlayan hava miktarı, havalandırma ihtiyacını belirler \\
\hline Çiçekçi & 8 & 8 & & \\
\hline Mobilya giyim & & & 1,5 & \\
\hline Hirdavat, ilaç & 8 & 8 & & \\
\hline Süpermarket & 8 & 8 & & \\
\hline Hayvanat & & & 5,0 & \\
\hline
\end{tabular}


Tablo 4. (Devam)

\begin{tabular}{|c|c|c|c|c|}
\hline \multicolumn{5}{|c|}{ Hesaplanan Minimum Dış Hava İhtiyacı } \\
\hline Uygulama & $\begin{array}{c}\text { İnsan } \\
\text { sayısı } \\
(\text { Kiși/100 } \\
\left.\text { m² }^{2}\right) \\
\end{array}$ & $\begin{array}{l}\text { l/s } \\
\text { kişi }\end{array}$ & $1 / \mathbf{s ~ m}^{2}$ & Açıklamalar \\
\hline $\begin{array}{l}\text { Spor ve } \\
\text { eğlence }\end{array}$ & & & & $\begin{array}{l}\text { Oyun alanlarının bakımı için içten yanmalı motorlu araçlar kullanılıyorsa } \\
\text { havalandırma miktarı arttırılmalıdır. }\end{array}$ \\
\hline Seyir salonları & 150 & 8 & & Nem kontrolü için daha yüksek değerler gerekebilir. \\
\hline Oyun salonları & 70 & 13 & & \\
\hline $\begin{array}{l}\text { Buz pisti (oyun } \\
\text { alanları) }\end{array}$ & & & 2,5 & \\
\hline $\begin{array}{l}\text { Yüzme } \\
\text { havuzları }\end{array}$ & & & 2,5 & \\
\hline Oyun katları & 30 & 10 & & \\
\hline $\begin{array}{l}\text { Disko ve balo } \\
\text { salonları }\end{array}$ & 100 & 13 & & \\
\hline $\begin{array}{l}\text { Bowling } \\
\text { salonları }\end{array}$ & 70 & 13 & & \\
\hline $\begin{array}{l}\text { Oteller, } \\
\text { moteller, } \\
\text { dinlenme } \\
\text { yerleri, yurtlar }\end{array}$ & & & & $\begin{array}{l}\text { Odaların boyutlarından bağımsız olarak (l/s oda), } \\
\text { Kesikli kullanım için tesis edilen kapasite } \\
\text { Yiyecek ve içecek hizmetler, alışveriş, berber ve güzellik salonları kısımlarına da } \\
\text { bakılır }\end{array}$ \\
\hline Yatak odaları & & & 15 & İlave duman uzaklaştırıcı cihaz gerekebilir \\
\hline Oturma odaları & & & 15 & \\
\hline Banyolar & & & 18 & \\
\hline Lobiler & 30 & 8 & & \\
\hline $\begin{array}{l}\text { Konferans } \\
\text { salonları }\end{array}$ & 50 & 10 & & \\
\hline $\begin{array}{l}\text { Toplantı } \\
\text { salonları }\end{array}$ & 120 & 8 & & \\
\hline $\begin{array}{l}\text { Yurt uyuma } \\
\text { alanları }\end{array}$ & 20 & 8 & & \\
\hline $\begin{array}{l}\text { Kumar } \\
\text { salonları }\end{array}$ & 120 & 15 & & \\
\hline Ofisler & & & & Bazı ofis cihazları yerel egzoz gerektirebilir \\
\hline Ofis alanları & 7 & 10 & & İlave duman uzaklaştırıcı cihaz gerekebilir \\
\hline Kabul alanları & 60 & 8 & & \\
\hline $\begin{array}{l}\text { Haberleşme } \\
\text { merkezleri }\end{array}$ & 60 & 10 & & \\
\hline $\begin{array}{l}\text { Konferans } \\
\text { salonlarl }\end{array}$ & 50 & 10 & & \\
\hline $\begin{array}{l}\text { Halka açık } \\
\text { alanlar }\end{array}$ & & & & Hiç geri dönüşsüz mekanik egzoz tavsiye edilir \\
\hline Koridorlar & & & 0,25 & \\
\hline $\begin{array}{l}\text { Genel } \\
\text { tuvaletler }\end{array}$ & & 25 & & \\
\hline $\begin{array}{l}\text { Soyunma } \\
\text { odaları }\end{array}$ & & & 2,5 & \\
\hline Sigara odaları & 70 & 30 & & $\begin{array}{l}\text { Normal olarak transfer havası ile beslenir } \\
\text { Geri dönüș (resirkülasyon) tavsiye edilmez }\end{array}$ \\
\hline Asansörler & & & 5,0 & Normal olarak transfer havası ile (komșu hacimlerden gelen) beslenir \\
\hline Tiyatrolar & & & & Özel sahne efektlerini karşılamak üzere özel havalandırma gerekecektir \\
\hline Bilet gișeleri & 60 & 10 & & \\
\hline Lobiler & 150 & 10 & & \\
\hline Salon & 150 & 8 & & \\
\hline $\begin{array}{l}\text { Sahne ve } \\
\text { stüdyolar }\end{array}$ & 70 & 8 & & \\
\hline Taşımacılık & & & & Taşıtlardaki havalandırma özel olarak ele alınmalıdır \\
\hline $\begin{array}{l}\text { Bekleme } \\
\text { salonları }\end{array}$ & 100 & 8 & & \\
\hline Platformlar & 100 & 8 & & \\
\hline Tașitlar & 150 & 8 & & \\
\hline & & & & $\begin{array}{l}-23^{\circ} \mathrm{C} \text { ile }+10^{\circ} \mathrm{C} \text { arasında tutulan hacimler eğer sürekli insan bulunmuyorsa bu } \\
\text { şartların kapsamına girmez. Komşu hacimlerden havalandırmaya müsaade edilir. }\end{array}$ \\
\hline El işleme & 10 & 8 & & $\begin{array}{l}\text { Soğuk odalara giriş çıkış yapılıyorsa meydana gelen enfiltrasyon yeterli } \\
\text { havalandırmayı sağlar }\end{array}$ \\
\hline $\begin{array}{l}\text { Fotoğraf } \\
\text { stüdyosu }\end{array}$ & 10 & 8 & & $\begin{array}{l}\text { Tesis edilecek cihaz zorlanmış egzoz ve arzu edilmeyen kirleticilerin kontrolü } \\
\text { özelliklerini sağlamalı. }\end{array}$ \\
\hline Karanlık oda & 10 & & 2,5 & \\
\hline Eczane & 20 & & & \\
\hline Banka & 5 & 8 & & \\
\hline $\begin{array}{l}\text { Fotokopi ve } \\
\text { baskı }\end{array}$ & 10 & 8 & 2,5 & \\
\hline
\end{tabular}


Tablo 5. Tavsiye edilen saatteki hava değişim sayıları (Öntaş 2008)

\begin{tabular}{|c|c|c|c|c|c|}
\hline Odanın özellikleri & $\begin{array}{c}\text { Saatteki hava } \\
\text { değişim } \\
\text { sayısı }\end{array}$ & $\begin{array}{c}\text { Tavsiye edilen } \\
\text { havalandırma } \\
\text { yöntemi }\end{array}$ & Odanın özellikleri & $\begin{array}{c}\text { Saatteki hava } \\
\text { değişim } \\
\text { sayısı }\end{array}$ & $\begin{array}{c}\text { Tavsiye edilen } \\
\text { havalandırma } \\
\text { yöntemi }\end{array}$ \\
\hline Toplantı salonları & 4-8 & Egzoz & Mutfaklar, domestik & $15-25$ & Egzoz \\
\hline Oditoryumlar & $6-8$ & Egzoz ve besleme & Mutfaklar, ticari & $15-30$ & Egzoz, ekipmanı \\
\hline Pasta, firın & $20-30$ & Egzoz & Laboratuvarlar & 8-15 & Kontrol \\
\hline Banyolar domestik & $5-7$ & Egzoz & Çamașırhaneler & $10-20$ & Egzoz, asit dirençli \\
\hline Banyolar genel & $7-10$ & Ön ısıttılmıș hava & Kütüphaneler & $4-5$ & Filtre tipi \\
\hline Güzellik salonları & $8-12$ & Egzoz ve besleme & Asansörler & $5-7$ & Egzoz \\
\hline Kafeler & $10-12$ & Egzoz & Asansör makine odası & $10-30$ & Egzoz ve besleme \\
\hline Kumarhaneler & $8-12$ & Egzoz ve besleme & Makine daireleri & $10-40$ & Egzoz \\
\hline Sinemalar & $5-8$ & Egzoz ve besleme & Ofisler & $4-8$ & Egzoz, ISı hesabı \\
\hline Vestiyer & $4-5$ & Egzoz & Lokantalar & $8-12$ & Egzoz, ISI hesabı \\
\hline Konferans salonları & $5-8$ & Egzoz ve besleme & Tuvaletler (ev) & 4-5 & Egzoz ve besleme \\
\hline Soyunma odaları & $6-8$ & Egzoz & Tuvaletler, genel & $8-15$ & Egzoz ve besleme \\
\hline Boyahaneler & $5-15$ & Alev geçirmez, asite & Dershaneler & $5-7$ & Egzoz \\
\hline Motor odaları & $15-30$ & Egzoz, ısıyı hesaplama & Dükkanlar & $4-8$ & Egzoz \\
\hline Dökümhaneler & $5-15$ & Egzoz, Isıyı hesapla & Dușlar & $15-25$ & Egzoz \\
\hline Garajlar & $5-7$ & Egzoz & Süpermarketler & $10-15$ & Egzoz \\
\hline Jimnastik salonları & $4-6$ & Egzoz & Yüzme havuzları & $10-15$ & Egzoz \\
\hline Kuaförler & $10-15$ & Egzoz & Tiyatrolar & $5-8$ & Egzoz ve besleme \\
\hline Hastaneler, hasta & $6-8$ & Egzoz & Kaynak atölyeleri & $20-30$ & Zonlamayı kontrol \\
\hline $\begin{array}{l}\text { Hastaneler, } \\
\text { Ameliyathaneler }\end{array}$ & $10-15$ & $\begin{array}{l}\text { Egzoz, besleme filtre } \\
\text { tipini kontrol etme }\end{array}$ & & & \\
\hline
\end{tabular}

\section{Sonuçlar}

Geçmiş yıllara oranla kapalı mekânlarda çalışmak modern toplumların temel çalışma sorunu olarak karşımıza çıkmaktadır. Kapalı yerlerde çalışmanın ve yaşamanın zorunlu olduğu günümüzde insanlar daha fazla rahatsızlanmaktadır. Sonuç olarak ekonomi ve iş gücü kayıplarına neden olmaktadır. HBS, iş haricinde alışveriş, barınma, öğrenim görme gibi nedenlerle vakitlerinin çoğunu kapalı mekanlarda geçiren günümüz insanının sosyal ilişskilerini de doğrudan etkilemektedir (Basak vd., 2016). Çalışma hayatının temel sorunları ile boğuşan insanların sosyalleşme amacıyla yine kapalı mekanları seçiyor olması, rekreatif mekan seçiciliğinin kapalı mekanlara yönelik olarak değişmesinin verdiği sağlıksız durumun devamı, bu mekanlarda daha kaliteli yaşam alanları sunulması amacıyla yaşanan yoğun rekreatif mekan işleticilerini de zor durumda bırakmaktadır. Bunlardan en önemlisi de iyi bir havalandırma ve iklimlendirme sistemlerinin kurulması ve bakımlarının sürekli ve iyi bir şekilde yapılması dahası bu hizmetin ekonomik sınırlar içinde olmasının sağlanması gelmektedir. Diğer yandan inşaatlarda uzun dönemde yavaş salınım yapabilecek kimyasal madde kullanımının sınırlandırılması, daha zararsız ve uçucu olmayan su bazlı malzemelerle ikame edilmesi gerekmektedir. Ayrıca bu tür kimyasal madde yayan ve özellikle ofislerde önemli bir yer tutan fotokopi makineleri ve tonerli yazıcılar gibi aygıtların özel odalarda tutulması ve bu odaların bağımsız olarak havalandırılmaları sağlanmalıdır. Sigara içiminin iç mekânlara etki eden kapı önleri veya teras gibi yerlerde yasaklanması da alınacak bir diğer önlemdir. Evlerde, okullarda ve ofislerde kullanılan mobilyaların ve buna benzer eşyaların Avrupa Birliği ve EPA standartlarına uygun olması, bu tür eşyaların ortam havasına uçucu kimyasalları yaymayacak şekilde kaliteli olmasına dikkat edilmelidir. Çalışanlar HBS konusunda bilgilendirilmeli, mümkünse ofislere otomasyona bağlı veya bireysel $\mathrm{CO}_{2}$ ölçüm cihazı yerleştirilmelidir. Cihaz alınamıyorsa çalışanların en azından sabah mesai başlangıç ve bitişi ile öğle ve çay-kahve aralarında odalarını havalandırma alışkanlığının kazandırılması gerekmektedir. Bu basit önlemlerle çalışan ve iş verimi artacak, HBS'ye bağlı hastalıklar ve şikâyetler azalacaktır.

\section{Çıkar Çatışması}

Yazarlar tarafından herhangi bir çıkar çatışması beyan edilmemiştir.

\section{Kaynaklar}

Abdul-Wahab, S., Salem, N., Ali, S. 2015. Investigation of the environmental indicators at the main library of Sultan Qaboos University (SQU) in the Sultanate of Oman. Sustain. Environ. Res., 25(3): 131-139

Ağca B., 2005. İç Hava Kalitesi ve Hasta Bina Sendromu, Uluslararası Ekonomik Sorunlar Dergisi, Sayl XVI, http://www.mfa.gov.tr/ichava-kalitesi-ve-hasta-bina-sendromu.tr.mfa. 
Alptekin, 0., 2007. Binalarda İç Hava Kalitesi Toz Partiküllerinin İç Mekân Hava Kalitesi Üzerindeki Etkilerinin İncelenmesi, Y.L. Tezi, Gazi Üniversitesi Fen Bilimleri Enstitüsü, Ankara.

Alyüz B., Veli S., 2006. İç Ortam Havasında Bulunan Uçucu Organik Bileşikler ve Sağlık Üzerine Etkileri, Trakya Univ J Sci, 7(2): 109-116.

Aslan, D.E., 1997. İç Hava Kalitesi ve Kontrolü. Makine Mühendisleri Odası, Teskon Program Bildirileri.

Basak S., Demirarslan K. O., Isik E., 2016. The Impact of Indoor Air Quality on Social Life. International Congress on Urban and Environmental Issues and Politics Congress Book, 625-632

Basak S., Demirarslan K. O., Isik E., 2017.

Determination of Indoor Air Quality of Different

Locations, International Journal of Agriculture,

Environment and Bioresearch. 2 (05): 393-407

Bulgurcu, H., İlten, N., Coşgun, A., 2008. Okullarda İç Hava Kalitesi Problemleri ve Çözümler, VII. Ulusal Tesisat Mühendisliği Kongresi ve Sergisi.

Çobanoğlu, N., Kiper, N., 2006. Bina İçi Solunan Havada Tehlikeler, Çocuk Sağlığı ve Hastalıkları Dergisi; 49: 71-75.

Coşgun A., 2008. Antalya İlinde bazı toplu çalışma alanlarındaki iç hava kalitesi üzerine bir araştırma. Y.L.Tezi, T.C. Sakarya Üniversitesi Fen Bilimleri Enstitüsü, Sakarya.

Demirarslan D., 2012. İç Mimarlık Öğrencileri İçin İç Mekan Tasarımına Giriș. Kocaeli Üniversitesi Yayınları. Yayın No: 228, Güzel Sanatlar Fakültesi Yayın No:2, Kocaeli.

Ersoy A., 2010. Hacettepe Üniversitesi Diş Hekimliği Fakültesi Binasında Çalıșma Ortam Koşullarının ve Hasta Bina Sendromu Ögelerinin Değerlendirilmesi, Y.L.Tezi, T.C. Hacettepe Üniversitesi Sağlık Bilimleri Enstitüsü, Ankara.

Ertürk M., 2017. Yatılı okul yatakhanelerinde iç hava kalitesi probleminin araștırılması ve yeni bir sistem geliştirilmesi, Sakarya Üniversitesi Fen Bilimleri Enstitüsü Dergisi, Doi:10.16984/saufenbilder.300751.

Eser, H.Ç., 2006. Konfor Kliması Uygulanan Hacimde Hız ve Sıcaklık Dağılımının İncelenmesi. Y. Lisans Tezi. Istanbul Teknik Üniversitesi - Fen Bilimleri Enstitüsü.

Gomzi, M., Bobic, J. 2009. Sick Building Syndrome, Do we live and work in unhealthy environment? Periodicum Biologorum. 111(1): 79-84.

Gou, Z., Lau, S.S.Y. 2012. A survey of sick building syndrome: Workplace design elements and perceived indoor environmental quality, Journal of Facilities Management, 10(4): 256-265.

Heslop, K. 2002. Personal and environmental characteristics, occupational factors and psychosocial correlates of sick building syndrome. Proceedings of indoor air 2002, Conference, 432-437. https://www.irbnet.de/daten/iconda/CIB7368. pdf
İstanbulluoğlu, H., Tekbaş, Ö.F. 2013. Kalıcı organik kirleticiler (KOK). Türk Hijyen ve Deneysel Biyoloji Dergisi, 70(3): 163-174.

Joshi, S.M., 2008. The Sick Building Syndrome, Indian Journal of Occupational and Environmental Medicine, 12 (2) 61-64.

Jansz, J. (2011). Theories and knowledge about sick building syndrome. In S. A. A. Wahab (Ed.), Sick building syndrome: in public buildings and workplaces (pp. 25-58).Springer.

Linder, R.K., 1995. Sick Building Case, IDC Quarterly, 5(2): 1-9.

Linyan, L., Adamkiewicz, G., Zhang, Spengler, Y., J.,D., Qu, F., Sundell, J. 2015. Effect of Traffic Exposure on Sick Building Syndrome Symptoms among Parents/Grandparents of Preschool Children in Beijing, China.

Menteşe S., Böce T., Mutlu M.B., Özdemirpençe S.S., Nişanci S.Y., Palaz E., Çetin B., Taşdibi D., Selçuk B., Karagöz S., 2013. Havadan Kaynakli Bakteri Seviyesinin Çanakkale'deki Ev, Yurt ve Okullarda Mekansal Değişimi. 11. ULUSAL TESISAT MÜHENDISLIĞ̈̇ KONGRESİ - 17/20 NISAN 2013/İZMIR.

Menteşe, S., Rad, A. Y., Arisoy, M., Güllü, G., 2009. İç Ortam Biyolojik Kirliliğin Mekansal Değişimi ve Diş Ortamin Etkisi. IX. ULUSAL TESISAT MÜHENDİSLİ̆́̇̇ KONGRESİ.

Nur, F.R., Juliana, J. 2012. Indoor Air Quality (IAQ) and Sick Buildings Syndrome (SBS) among Office Workers in New and Old Building in Universiti Putra Malaysia, Serdang. Health and the Environment Journal, 3(2): 98-109

Obi, I.C., 2015. Strategic Management in Building Designs for Sick Building Syndrome Control: The Effect of Ideal Building Orientation, ARP International Journal of Social Science, 1(1): 1323.

Okolie, K.C., Adedeji, C.,Y. 2013. Investigation into the Effects of Sick Building Syndrome on Building Occupants: A Case Study of Commercial Bank Buildings in Awka Nigeria. International Journal of Engineering Research and Development, 6(6): 47-53

Öntaş E., 2008. Kapalı Hacimlerde Slot Difüzör Kullanımının Hava Dağılımına Etkisi, Y.L.Tezi, İstanbul Teknik Üniversitesi, Fen Bilimleri Enstitüsü.

Otlu M., 2012. Turgut Özal Tip Merkezi Çalışanlarında Hasta Bina Sendromu Görülme Sıklıği ve Etkileyen Faktörler, Uzmanlık Tezi, T.C. İnönü Üniversitesi Tıp Fakültesi, Malatya.

Özyaral, O., Keskin, Y., 2005. Kapalı Alan Atmosferinin Sağlık Üzerine Etkileri: Kakosmi (Kötü Koku) Sendromu. Astım Allerji İmmünoloji ;3(2):86-96.

Quagraine V., Boschi N., 2006. "Behavioral changes can help prevent indoor air - related illness in Ghana", Building and Environment, 10: 1 - 54.

Sahlberg, B., Smedje, G., Norback, D., 2002. Sick buildıng syndrome (sbs) among school 
employees in the county of Uppsala, Sweden, Proceedings: Indoor Air 2002, www.irbnet.de/daten/iconda/CIB7173.pdf.

Salleh, N.M., Kamaruzzaman S.N., Mahyuddin N. 2013. Sick building symptoms among children in private pre-schools in Malaysia: association of different ventilation strategies. Journal of Building Performance, 4(1): 73-81.

Sunaç, B. ve Kenber, E., 2000. Havalandırma Tesisatı, Alarko yayınları.

URL-1

https://en.wikipedia.org/wiki/Sick_building_sy ndrome

URL-2 The Environmental Illnes Resource, www.eiresource.org

URL-3, http://www.ashrae.org.tr

Zeybek, I., 2014. Modern Yaşamin Göstergelerinden Yüksek Binalarda Renk - Ișık Faktörü Bağlamında "Hasta Bina Sendromu" ve İletişimsel Boyutta Etkileri. The Turkish Online Journal of Design, Art and Communication TOJDAC October 2014 Volume 4 Issue 4 